\title{
PENGARUH METODE INKUIRI TERHADAP KEMAMPUAN MEMBACA INTENSIF PADA PEMBELAJARAN BAHASA INDONESIA SISWA KELAS IV SDN JURUMUDI 3 KECAMATAN BENDA KOTA TANGERANG
}

\author{
${ }^{1}$ Ade Choirunisa, ${ }^{2}$ Dilla Fadhillah, ${ }^{3}$ Hamdah Siti Hamsanah Fitriani \\ $\mathbf{1 , 2 , 3}$ Universitas Muhammadiyah Tangerang, \\ choirunisa.ade2@gmail.com, dillafadhillah89@gmail.com, vitrianivit@gmail.com
}

\begin{abstract}
Abstrak
Penelitian ini bertujuan untuk mengetahui a da a tau tidaknya pengaruh penggunaan me to de in k u iri terh adap kemampuan membaca intensif. Penelitian ini dilaksanakan di Sekolah Da sar Negeri Ju ru m udi 3 Ke ca matan Benda Kota Tangerang, kelas IV semester II tahun ajaran 2018-2019. Metode yang digunakan dalam penelitian ini a da lah quasi eksperimen. Adapun sampel penelitia n ini meliputi 27 siswa kelas eksperimen d an 27 sis wa kela s kontrol. Kelas IV-A sebagai kelas eksperimen dan kelas IV-B sebagai kela s k ontrol. In strumen y ang digunakan adalah tes sebanyak 10 soal. Teknik analisis data yang digunakan untu $\mathrm{k}$ menguji hip otesis yaitu dengan uji-t, pada taraf signifikan $\alpha=0,05$ dan derajat kebebasan $(\mathrm{dk})=54$. Uji normalitas hasil tes menggunakan chi kuadrat. Pada kelompokeksperimen $x^{2}{ }_{\text {hitung }}=1.332$ pada $\alpha=0.05 \mathrm{dan} x_{\text {tabel }}{ }^{2}=11.070$. Pada kelompok kontrol $x^{2}{ }_{\text {hitung }}=9.838$ pada $\alpha=0.05$ dan $x_{\text {tabel }}^{2}=11.070$. Pada kedua kelompok berdistribusinormal. Uji homogenitas menggunakan uji Fisher. Diperoleh $\mathrm{F}_{\text {hitung }}=1.146 \mathrm{dan} \mathrm{F}_{\text {tabel }}=1.929$ pada $\alpha=0.05$. Sehingga $1.146<1.929=\mathrm{F}_{\text {tabel }}$ maka disimpulkan bahwa kedua varians populasi adalah sa ma ata u homogen. Uji a nalisis dan menggunakan uji-t yang diperoleh $t_{\text {hitung }}$ sebesar $5.147 \mathrm{dan} t_{\text {tabel }} 2.006 \mathrm{pada}$ taraf signifikan $\alpha=0.05$ sehingga $t_{\text {hitung }}>t_{\text {tabel }}(5.147>2.006)$ maka dapat disimpulkan $H_{1}$ diterima ini menunjukkan bahwa terdapatperbedaan kemampuan membaca intensif yang mendapat pembelajaran menggunakan metode inkuiri dengan siswa yang men dapat pembelajaran dengan menggunakan model pembelajaran konvesional. Dari data yang sudah didapat seperti yang dicantumkan, dapat disim pulkan bahwa terdapat pengaruh metode pembelajaran inkuiri terhadap kemampuan membaca intensif pada siswa kelas IV SDN Jurumudi 3 Kecamatan Benda Kota Tangerang.
\end{abstract}

Kata Kunci: Metode Inkuiri. Membaca Intensif Kelas IV

\begin{abstract}
This study aims to determine whether or not the influence of the use of inquiry method on in tensive rea ding skills. This resea rch was conducted in the state elementary school jurumudi 3 ta ngerang city, grade IV. Semester two of the 2018-2019 schoolyear. The method used in this research is quasi experiment. The sample of this research included twentyseven students of the experiment class and twentyseven students of the co nt rol cla ss. The instrument used was test of ten questions. The data analysis technique used to test the hypoth esis is the $t-$ test, on level significa nce $\alpha=0,05$ and degrees of freedom $(\mathrm{dk})=54$. Normality test result using the Chi Square. Homogeneity test uses Fisher test. Was obtained $\mathrm{F}_{\text {count }}=1.146$ and $\mathrm{F}_{\text {table }}=1.929$ on $\alpha=0.05$. So that $1.146<$ $1.929=\mathrm{F}_{\text {table }}$ it is concluded that the two population variance are the sameor homogeneous. Analysis te st and using the $t$-test obtained diperoleh $t_{\text {count }}$ of 5.147 dan $_{\text {table }} 2.006$ on level significance $\alpha=0.05$ so that $t_{\text {count }}$ > $t_{\text {table }}(5.147>2.006)$ it can be conclu ded $\mathrm{H}_{1}$ this acceptance shows that there are differences in intensive reading skills that are get learning using the Inquiry method with students who get lea rning using convetional le a rning models. From the data already obtained as stated, it can be concluded that there is an influence of Inquiry learning method on intensive reading skills in grade IV SDN Jurumudi 3 tangerang city.
\end{abstract}

Key words: Inquiry method. Intensive reading class IV 


\section{PENDAHULUAN}

Pendidikan merupakan hak untuk semua manusia tanpa membeda-bedakan status maupun kondisi apapun. Akan tetapi selama ini pendidikan reguler, khususnya di tingkat Sekolah Dasar sebagian besar hanya diperuntukan untuk anak-anak dengan keadaan normal. Hal ini menimbulkan suatu ketimpangan sosial, banyak dari peserta didik yang tidak bisa berinteraksi secara baik dengan anak yan g memiliki kebutuhan khusus. Sehingga diperlukan suatu upaya untuk menanganinya. Selain itu, pendidikan kita masih tersandung masalah biaya. Khususnya bagi masyarakat dengan kebutuhan khusus, mereka harus masuk ke dalam sekolah luar biasa. Memang sebagian di daerah di perkotaan sudah terdapat instansinya. Namun di daerah lain, khususnya di pedesaan masih jarang sekali sekolah luar biasa. Sehingga harapan untuk sekolah dan mendapatkan pendidikan sangat sulit sekali.

Berdasarkan undang-undang Republik Indonesia Nomor 20 Tahun 2003 di atas, usaha sadar dan terencana yang dimaksudkan dalam pengertian pendidikan tersebut merupakan usaha yang dilakukan oleh semua komponen baik orang tua, guru dan peserta didik untuk lebih menyadari bahwa pendidikan sangatlah penting bagi kehidupan kita. Selain itu juga harus bisa mewujudkan suasana belajar ya ng baik dan mengembangkan proses pembelajaran yang aktif untuk lebih menge mbangkan segala potensi yang ada pada masing-masing individu. Sehingga dapat bermanfaat untuk masa depan para peserta didik bagi dirinya sendiri, masyarakat, bangsa maupun negara.

Berdasarkan hasil observasi pada tanggal 29 Oktober 2018 di kelas IV SDN Jurumudi 3 di kelas IV SDN Jurumudi 3 menunjukkan bahwa kelemahan dalam pembelajaran Bahasa Indonesia disebabkan oleh guru menggunakan metode ceramah dan siswa tidak menjadi paham dalam proses pembelajaran Bahasa Indonesia. Hal ini menyebabkan proses pembelajaran yang dilakukan oleh guru hanya satu arah, sehingga pemahaman dalam berfikir dan mengembangkan materi kurang. Dampak lainnya adalah siswa merasa tidak tertarik dalam pembelajaran Bahasa Indonesia akibatnya siswa malas untuk membaca sehingga nilai rata-rata siswa tergolong rendah.

Berdasarkan hasil wawancara dengan guru Bahasa Indonesia di SDN Jurumudi 3 Kota Tangerang, didapatkan data nilai bahwa KKM (Kriteria Ketuntasan Minimal) untuk pelajaran Bahasa Indonesia yang di targetkan yaitu nilai 70 dan masih banyak siswa yang masih mendapatkan nilai di bawah KKM dalam mata pelajaran Bahasa 
Indonesia pada kelas IV. Di kelas IV hanya terdapat $60 \%$ siswa yang sudah mencapai nilai KKM, sedangkan $40 \%$ siswa lainnya mendapatkan nilai di bawah KKM. Tidak maksimalnya proses pembelajaran Bahasa Indonesia yang terjadi di kelas IV siswa yang kurang dalam kemampuan membacanya sehingga rendahnya nilai ulangan. Padahal tidak bisa dipungkiri kemampuan membaca sangat diperlukan oleh setiap orang. Terutama untuk anak yang ingin memperluas pengetahuan dan pengalaman untuk mencapai kemajuan diri dalam masa depannya kelak.

Pemilihan metode belajar yang tepat juga bisa menunjang keberhasilan siswa dalam pemahaman materi. Karena itu, diperlukan metode belajar yang tepat untuk mengarahkan siswa lebih aktif dan termotivasi. Dalam penelitian pada sekolah ini untuk mengatasi proses pembelajaran bahasa indonesia dengan melakukan suatu metode baru dalam proses belajar mengajar agar pembelajaran bahasa indonesia tidak lagi siswa merasa jenuh dan membosankan, yaitu menerapkan strategi pembelajaran yang mendorong siswa untuk aktif dalam pembelajaran. Salah satunya yaitu metode inkuiri. Metode inkuiri adalah metode pembelajaran di mana siswa dituntut untuk lebih aktif dalam proses pembelajaran, diharapkan siswa didorong untuk belajar melalui keterlibatan aktif pada proses berpikir secara kritis dan analitis untuk mencari dan menemukan sendiri jawaban dari suatu masalah. Karena jika peserta didik mampu belajar lebih aktif maka mereka akan mampu menghasilkan semangat dan keinginan untuk belajar yang lebih, sehingga siswa mampu menangkap materi yang disampaikan secara lebih maksimal dan mudah dipahami.

Identifikasi masalah pada pembelajaran ini adalah: Pembelajaran Bahasa Indonesia siswa kurang intens dalam membaca intensif, Rendahnya nilai siswa pada pembelajaran Bahasa Indonesia, Metode inkuiri belum pernah diterapkan di kelas IV SDN Jurumudi 3 Kota Tangerang, Guru lebih banyak menggunakan metode konvesional dalam mengajar, Siswa kurang aktif dan berfikir kritis dalam pembelajaran. Dalam penelitian ini. maka peneliti hanya meneliti metode inkuiri dan kemampuan membaca intensif pada pembelajaran bahasa Indonesia siswa kelas IV SDN Jurumudi 3 Kota Tangerang. Rumusan masalah. Peneliti merumusakan “Apakah terdapat perbedaan kemampuan membaca intensif antara siswa yang diberi metode inkuiri dengan siswa yang diberi metode konvesional?". Adapun tujuan penelitian ini adalah untuk mendeskripsikan apakah terdapat perbedaan kemampuan membaca intensif antara 
siswa yang diberi metode inkuiri dengan siswa yang diberi metode konvesional. Adapun manfaat dari penelitian ini terbagi menjadi 2 yaitu teoritis dan praktis.

\section{KAJIAN TEORI}

Kemampuan membaca intensif adalah kemampuan memahami detail secara akurat, lengkap , dan kritis terhadap fakta, konsep, gagasan, pendapat, pengalaman, pesan, dan perasaan yang ada pada wacana tulis. Menurut Mulyati (2015) Membaca intensif merupakan kegiatan membaca yang dilakukan secara cermat untuk memperoleh pemahaman terhadap teks bacaan secara tepat dan akurat (h.4.6). Berdasarkan uraian tersebut dalam membaca intensif setiap siswa dalam membaca tek $\mathrm{s}$ harus membaca dengan cermat sehingga setiap membaca siswa dapat memahami isi teks bacaan secara tepat dan akurat.

Menurut Tarigan (2015) Menjelaskan studi saksama, telaah teliti, dan penanganan terperinci yang dilaksanakan di dalam kelas terhadap suatu tugas yang pendek kira-kira dua sampai empat halaman setiap hari. Kuesioner, latihan pola-pola kalimat, latihan kosa kata, telaah kata-kata, dikte, dan diskusi umum merupakan bagian dan teknik membaca intensif (h.36). Kegiatan membaca ini melibatkan aktivitas kognitif dalam berbagai tataran.

Metode inkuiri adalah rangkaian kegiatan pembelajaran yang menekank an para proses berpikir secara kritis dan analitis untuk mencari dan menemukan sendiri jawaban dari suatu masalah yang dipertanyakan. metode inkuiri ini lebih menekankan siswa agar berpikir kritis dan analitis dalam pembelajaran, sehingga pembelajaran yang menurut siswa sulit, siswa harus berpikir untuk mencari dan menemukan sendiri jawaban dari masalah tersebut.

\section{METODOLOGI PENELITIAN}

Penelitian ini dilakukan di SDN Jurumudi 3 Kota Tangerang yang berletak di Jl. Halim Perdana Kusuma. Kelurahan : Jurumudi. Kecamatan : Benda. Kota Tangerang. Penelitian ini menggunakan pendekatan kuantitatif metode eksperimen yang digunakan dalam penelitian ini adalah (quasi eksperimen). Rancangan penelitian ini adalah rancangan Nonequivalent Control Group Desain menurut Riadi (2014) seperti yang digambarkan dalam tabel berikut ini (h.14). 
Tabel 3.2 Rancangan Nonequivalent Control

\begin{tabular}{|c|c|c|c|}
\hline Kelompok & Pretest & Perlakuan & Postest \\
\hline Eksperimental & $\mathrm{Y}_{\mathrm{E}}$ & $\mathrm{X}$ & $\mathrm{Y}_{\mathrm{E}}$ \\
\hline Kontrol & $\mathrm{Y}_{\mathrm{K}}$ & - & $\mathrm{Y}_{\mathrm{K}}$ \\
\hline
\end{tabular}

Populasi dalam penelitian ini adalah seluruh siswa kelas IV SDN P 4 Kota Tangerang yang berjumlah 54

Tabel 3.3 Populasi

\begin{tabular}{|c|c|c|}
\hline Kelas & IV A & IV B \\
\hline Jumlah/Kelas & 27 & 27 \\
\hline Total & \multicolumn{3}{|c|}{54} \\
\hline
\end{tabular}

Kemudian sampel yang dijadikan peneliti adalah siswa kelas IV A sebagai kelas eksperimen dan kelas IV B sebagai kelas kontrol dengan jumlah 54 siswa. Teknik pengumpulan data pada penelitian ini adalah wawancara, tes, dan dokumentasi.

\section{HASIL DAN PEMBAHASAN}

\section{Hasil pretest kelas kontrol dan kelas eksperimen}

Pada kelompok kelas kontrol yaitu kelas IV B yang menggunakan diperoleh nilai tertinggi 72 dan nilai terendah yaitu 38 dengan rata-rata 55.6. Median 56.46. Modus 57.75. Adapun Varians $\left(\mathrm{S}^{2}\right)$ yang didapat sebesar 70.26. Dengan simpangan baku (S) sebesar 8.38. Sedangkan untuk kelas eksperimen yaitu kelas IV A yang menggunakan diperoleh nilai tertinggi 74 dan nilai terendah 40 dengan rata-rata 58.94. Median $=$ 59.6. Modus $=60.77$. Adapun Varians $\left(S^{2}\right)$ yang didapat sebesar 68.10. Dengan simpangan baku (S) sebesar 8.25. Selanjutnya dilakukan uji normalitas untuk kelas pretest kontrol dan eksperimen dan Pada kelas kontrol menunjuk an bahwa data berdistribusi normal yaitu $X^{2}$ hitung $2.391<X^{2}$ tabel 11.070 . Untuk uji normalitas kelas eksperimen menunjukan bahwa data berdistribusi normal yaitu $X_{\text {hitung }}^{2} 2.582<X_{\text {tabel }}$ 11.070. selanjutnya dilakukan uji homogenitas pretes kelas kontrol dan eksperimen. Dalam uji homogenitas data kedua varian adalah homogen yaitu $F_{\text {hitung }} 1.066<F_{\text {tabel }}$ 1.929. Selanjutnya dilakukan uji hipotesis pretes kelas kontrol dan eksperimen 
menunjukan bahwa tidak terdapat perbedaan kemampuan membaca intensif kelas kontrol dan eksperimen, dapat dilihat dari nilai $t_{\text {hitung }} 1.156<t_{\text {tabel }} 2.006$.

\section{Hasil postest kelas kontrol dan kelas eksperimen}

Pada penelitian ini yang menjadi kelas eksperimen yaitu kelas IV A. Yang menggunakan metode inkuiri diperoleh nilai tertinggi 100 dan nilai terendah yaitu 72 dengan rata-rata 88.07. Median 88.68. Modus 88.5. Adapun Varians ( $\left.\mathrm{S}^{2}\right)$ yang didapat sebesar 88.07. Dengan simpangan baku (S) sebesar 7.076. Sedangkan untuk postest kelas kontrol yaitu kelas IV B yang menggunakan metode konvesional diperoleh nilai tertinggi 94 dan nilai terendah 60 dengan rata-rata 76.72. Median 79.6, Modus 79.78. Adapun Varians $\left(\mathrm{S}^{2}\right)$ yang didapat sebesar 60.64. Dengan simpangan baku (S) sebesar 7.78. Selanjutnya dilakukan uji normalitas untuk kelas eksperimen dan kontrol. Pada kelas eksprimen menunjukan bahwa data berdistribusi normal yaitu $X^{2}{ }_{\text {hitung }} 1.332<$ $X_{\text {tabel }}^{2}$ 11.070. Untuk uji normalitas postest kelas kontrol menunjukan bahwa data berdistribusi normal yaitu $X^{2}{ }_{\text {hitung }} 9.838<X_{\text {tabel }}^{2} 11.070$. Selanjutnya dilakukan uji homogenitas postes kelas eksperimen dan postest kelas kontrol. Dalam uji homogenitas data kedua varian adalah homogen yaitu $F_{\text {hitung }} 1.146<F_{\text {tabel }} 1.929$. Selanjutnya dilakukan uji hipotesis postes kelas eksperimen dan postest kelas kontrol menunjukkan bahwa tidak terdapat perbedaan kemampuan membaca intensif siswa kelas eksperimen dan kontrol, dapat dilihat dari nilai $t_{\text {hitung }} 5.147>t_{\text {tabel }} 2.006$ karena $t_{\text {hitung }}$ lebih besar dari $t_{\text {tabel }}$ maka $\mathrm{H}_{\mathrm{o}}$ ditolak, artinya terdapat pengaruh kemampuan membaca in ten sif antara siswa yang mendapat pembelajaran menggunakan metode inkuiri dengan siswa yang mendapat pembelajaran dengan menggunakan metode konvesional pada siswa kelas IV SDN Jurumudi 3.

Dengan demikian hasil penelitian ini menunjukan bahwa siswa yang menggunakan metode inkuiri lebih meningkatkan kemampuan membaca intensif dibandingkan siswa yang menggunakan metode konvesional, hal ini dikarenakan terdapat pengaruh perlakuan pada saat proses pembelajaran. Sehingga tidak terdapat perbedaan yang signifikan antara kelas Eksperimen dan Kontrol. Sedangkan untuk nilai postest kelas Eksperimen memperoleh nilai rata-rata sebesar 88,07. Sedangkan untuk kelas postest kontrol memperoleh nilai rata-rata sebesar 77,72. Pada hasil postes kedua kelas mengalami peningkatan dari pretest. Hal ini dikarenakan hasil posttest dilakukan setelah adanya perlakuan. Jika dibandingkan, kelas Eksperimen yang menggunakan 
metode inkuiri lebih meningkatkan kemampuan membaca intensif siswa dibandingkan dengan kelas Kontrol yang menggunakan metode konvesional.

Hasil analisis postes Uji-t diperoleh nilai $t_{\text {hitung }} 5,147$ pada taraf signifikan a $=$ 0,05. Dari hasil perhitungan tersebut diperoleh $t_{\text {hitung }}(5,147)<t_{\text {tabel }} 2,006$ maka hipotesis penelitian $\mathrm{H}_{\mathrm{o}}$ ditolak dan $\mathrm{H}_{\mathrm{I}}$ diterima, maka terdapat pengaruh kemampuan membaca intensif yang diberi perlakuan metode inkuiri dengan siswa yang mendapat pembelajaran dengan menggunakan konvesional. Sehingga dapat disimpulkan metode inkuiri memiliki pengaruh yang lebih tinggi dibandingkan dengan siswa yang mendapat pembelajaran dengan menggunakan konvesional terhadap kemampuan membaca intensif pada pembelajaran bahasa Indonesia pada siswa kelas IV SDN Jurumudi 3 Krcamatan benda Kota Tangerang.

\section{KESIMPULAN}

Berdasarkan hasil penelitian dan pengujian hipotesis yang telah dilakukan metode pembelajaran yang digunakan oleh guru tidak dapat mempengaruhi tes hasil belajar kemampuan membaca intensif pada siswa kelas IV SDN Jurumudi 3 Kecamatan Benda Kota Tangerang. Diperoleh nilai rata-rata pretes pada kelas pretes eksperimen (IV-A) yaitu 58,94, sedangkan untuk kelas pretes kontrol (IV-B) memperoleh nilai ratarata pretes sebesar 55,6. Dari hasil pretes ini kedua kelas memiliki nilai rata-rata y ang tidak terlalu jauh. Sehingga tidak terdapat perbedaan yang signifikan antara kelas Eksperimen dan Kontrol. Sedangkan untuk nilai postest kelas Eksperimen memperoleh nilai rata-rata sebesar 88,07. Sedangkan untuk kelas kontrol memperoleh nilai rata -rata sebesar 76,72. Pada hasil postest kedua kelas mengalami peningkatan dari pretest. Hal ini dikarenakan hasil postest dilakukan setelah adanya perlakuan. Jika dibandingkan kelas Eksperimen yang menggunakan metode inkuiri lebih meningkatkan pengaruh kemampuan membaca intensif siswa dibandingkan dengan kelas Kontrol yang menggunakan metode konvesional.

Hasil Uji norrmalitas hasil tes menggunakan chi kuadrat pada kelompok eksperimen $\mathrm{x}^{2}$ hitung $=1.332$ dan $\mathrm{x}^{2}$ tabel $=11.070$ pada taraf signifikan $\alpha=0.05$ untuk jumlah siswa perkelas $(n=27)$, sehingga $x^{2}$ hitung $(1.332)<x^{2}$ tabel (11.070). Dengan demikian dapat disimpulkan bahwa data berdistribusi nomal. Uji homogenitas hasil tes menggunakan uji Fisher diperoleh $\mathrm{f}_{\text {hitung }}=1.146$ dan $\mathrm{f}_{\text {tabel }}=1.929$. Sehingga $1.146<$ 
$1.929\left(\mathrm{f}_{\text {hitung }}<\mathrm{f}_{\text {tabel }}\right)$. Dengan demikian dapat disimpulkan bahwa kedua varians populasi adalah sama atau homogen. Hasil perhitungan uji hipotesis didapatkan data postest sebesar 5.147 pada taraf signifikasi $\alpha=0.05$ dengan diperoleh $t_{\text {tabel }} 2.006$ pada data postest $t_{\text {hitung }}>t_{\text {tabel }}$ maka $\mathrm{H}_{\mathrm{o}}$ ditolak dan $\mathrm{H}_{1}$ diterima, yang berarti bahwa terdapat perbedaan rata-rata nilai tes hasil belajar kemampuan membaca inten sif sis wa antara kelas kontrol dan kelas eksperimen, dengan demikian adanya pengaruh metode inkuiri terhadap kemampuan membaca intensif pada siswa kelas IV SDN Jurumudi 3 Kecamatan Benda Kota Tangerang.

\section{SARAN}

Berdasarkan hasil penelitian yang diperoleh maka, penulis memberikan beberapa saran antara lain:

1. Sekolah diharapkan dapat ikut serta menciptakan kondisi yang aktif bagi guru untuk melaksanakan kegiatan pembelajaran dengan menggunakan metode khususnya metode inkuiri sehingga metode yang dapat meningkatkan hasil belajar peserta didik.

2. Jika guru ingin mendapatkan nilai tes hasil belajar yang optimal, maka harus menggunakan variasi-variasi dalam pembelajaran salah satunya dengan menggunakan metode-metode pembelajaran lainnya.

3. Siswa hendaknya dapat merubah persepsi negatif pada pembelajaran bahasa Indonesia, misalnya siswa yang menganggap pembelajaran bahasa Indonesia pembelajaran yang sangat sulit dipahami dan tidak bersemangat.

\section{DAFTAR PUSTAKA}

Aidin, Yunus \& Sriasturi. (2013). Pembelajaran Bahasa Indonesia Bagi Penutur Asing. Bandung: Rizki Press.

Anitah, Sri. (2017). Strategi Pembelajaran di SD. Tangerang Selatan : Universitas Terbuka.

Arikunto, Suharsimi. (2014). Prosedur Penelitian. Jakarta : Rineka Cipta.

Dalman. (2017). Keterampilan Membaca. Jakarta : PT Raja Grafindo Persada. 
Hamdayana, Jumanta. (2017). Model dan Metode Pembelajaran Kreatif dan Berkarakter. Bogor: Ghalia Indonesia.

Harras Kholid, dkk (2018). Membaca 1. Tangerang Selatan : Universitas Terbuka.

Juleha. (2013). Pembelajaran Bahasa Indonesia. Bandung: PT Remaja Rosdakarya.

Kadir. (2015). Statistika Terapan. Jakarta : PT Raja Grafindo Persada.

Mulyati, Yeti. (2015). Bahasa Indonesia. Tangerang Selatan : Universitas Terbuka.

Nara, Hartati, dan Siregar, Evaline. (2010). Teori Belajar dan Pembelajaran. Bogor :

Ghalia Indonesia.

Nurgiyantoro, Burhan. (2014). Penilaian Pembelajaran Bahasa. Yogyakarta : BPFE Yogyakarta.

Riadi, Edi. (2014). Metode Statistika Parametrik \& Nonparametrik. Tangerang: Pustaka Mandiri.

Sanjaya, Wina. (2016). Strategi Pembelajaran Beriorentasi Standar Proses Pendidikan. Jakarta : Prenada Media Group.

Sani, Abdullah, Ridwan. (2016). Inovasi Pembelajaran. Jakarta : PT Bumi Aksara.

Shoimin, Aris. (2014). Model Pembelajaran Inovatif dalam Kurikulum 2013. Depok: AR-Ruzz Media.

Subana dan Sunarti. (2011). Strategi Belajar Mengajar Bahasa Indonesia. Bandung: Pustaka setia.

Sugiyono, Dr. (2018). Metode Penelitian Kuantitatif. Bandung: Alfabeta, cv

Tarigan, Guntur. (2015). Membaca Sebagai Suatu Keterampilan Berbahasa. Bandung : CV Angkasa.

Taufina, Dr. (2016). Mozaik Keterampilan Bahasa di Sekolah Dasar. Bandung : Cv Angkasa.

Wahhid, Iskandar. (2016). Strategi Pembelajaran Bahasa. Bandung : PT Remaja Rosdakarya Offset.

Yamin, Martinis. (2013). Strategi dan Metode dalam Model Pembelajaran. Jakarta: Referensi (GP Group. 